\title{
ANALYSIS OF MERGER \& ACQUISITION MOTIVES IN INDONESIAN LISTED COMPANIES THROUGH FINANCIAL PERFORMANCE PERSPECTIVE
}

\section{Josua Tarigan ${ }^{1}$, Alfonsis Claresta ${ }^{2}$, Saarce Elsye Hatane ${ }^{3}$ 1,2,3 Petra Christian University}

\author{
josuat@petra.ac.id
}

\begin{abstract}
This study aims to analyse the financial performance of Indonesia companies undergoing M\&A in the period of 2009-2012 by comparing several accounting ratios from four years before and after M\&A. The sample of this study is 136 annual reports, ranged from 2005 until 2016 of non-banking companies in Indonesia Stock Exchange (IDX). The financial performance of the companies was assessed by several ratios, to measure accounting and market measurement simultaneously to fully assess the M\&A performance. The mean of these ratios from four years before was being compared to the mean from four years after M\&A; using Paired Sample T-Test, Wilcoxon Signed Rank Test and MANOVA. The test done showed that most of the Indonesian companies undergoing M\&A are (a) pursuing for growth and financial synergy motives (b) operating synergies objective needs longer time to be achieved, and (c) accounting and market measurement had been in line revealing semi-strong form of market efficiency in Indonesia.
\end{abstract}

Keywords: Merger and Acquisition, Motives, Financial Performance, Market measurement, Indonesia.

JEL $\quad:$ G34; M41

DOI $\quad: 10.24002 /$ kinerja.v22i1.1570

Received : 06/02/2018 Reviewed : 10/02/2018 Final Version : 20/02/2018 


\section{INTRODUCTION}

Current business world has been significantly different compared just to 25 years ago. Globalization has been one main factor causing all the differences; thanks to the Internet. Companies are now open to global competition as the old trade barriers have now been disappeared. It allows companies to grow faster than ever and provide customers with a numerous amount of options. This situation has brought Mergers and Acquisition (M\&A) embraced a new wave, called globalization wave and become the most realistic and important business strategy in this era (Carrey, 2000). Tamosiuniene and Duksaite (2009) stated that M\&A have become common business tools as many potential benefits which mainly focus on boosting profits and shareholder value can be obtained through economies of scale, expanded use of existing resources, extension of product, and diversification of risks.

Not only does this happen in the developed countries, but also in the developing countries inevitably. Currently in South-East Asia, ASEAN Economic Community (AEC), where trading between South-East Asian countries will get borderless, has major impact on the development of business world in all SouthEast Asian countries including Indonesia.Indonesia now contributes to $35 \%$ of the ASEAN's GDP and represents $40 \%$ of the region's population. Its middle class and young population dominates the country's economic activities and it stands now at a stable $6 \%$ growth rate. Indonesia is expected to be one of the world's 10 biggest economies by 2025. By 2030, Indonesia will have about 90 million new consumers, providing more good reasons to invest in the country as its 250 million population is the fourth biggest in the world (Halim, 2016).

The government has also prepared the country to be ready to face the obstacles in this dynamic business world by giving incentives for international or multinational companies to come or give direct investments and compete with the locals so they can learn and raise their own standard. The country has opened the door more widely than ever for some business sectors for example manufacturing, agriculture, marine, infrastructure, and tourism industries (Halim, 2016). Nonetheless, these huge features and opportunities are often overlooked by prospectors.

The number of M\&A deals and value in Indonesia peaked in 2012, but then dropped in terms of number of transaction and value of deals, especially during 2013-2015 (Duff \& Phelps Singapore Pte Ltd, 2016). However, the number of M\&A transaction made has increased and the value of the transaction has significantly recovered in 2016 dominated by domestic transactions due to economic "packages" introduced by President Joko Widodo aiming to improve competitiveness and attract investments (Timmerman, 2017). According to Tegos (2016), this increase is predicted to be continued in 2017 as a restructuring in technology industry is rampant.

The determination of the successful M\&A can be seen from the financial performance of the company. Financial performance of company plays an important role in keeping track of the progress of the company. It gives the overview of the situation faced by company and acts as a basis of the target that will be set by the company in the incoming period. Through comparison of financial statements from previous years, the tendency and dynamics of changes of some elements can be predicted, so that a management of company can estimate business efficiency and security which shows the business quality. The ratio of financial performance, thus, 
will be very useful in estimating the current business quality and creating assumption for more successful business in the future (Zager \& Zager, 2006). Carrey (2000) also stated that the measurement of M\&A results can be shown by the profitability, liquidity, leverage, and efficiency ratios by the company before and after M\&A period. The improvement in these ratios can indicate that the company has successfully achieved the financial and operational synergies between two newly combined companies.

Theoretically, M\&A must have given advantages to the companies and, therefore, the financial performance analysed through financial ratios should be getting better. However, previous studies using accounting ratios as indicator to measure whether $M \& A$ in Indonesia has caused any significant difference in financial performance of the companies showed that M\&A had slightly to none impact on financial performance.

The first reason of this result is that most research conducted for companies underwent M\&A for quite long time scale. The results, therefore, did not truly represent the current situation of $M \& A$ analysis in Indonesia. Many have changed in a very short period of time in this contemporary business world; not to mention the different part of business cycle experienced in that time range. Nowadays, companies may have been more experienced and have had more knowledge and insights to manage M\&A compared to five or ten years ago.

The second reason of this result is the period of the study. Most studies had been done for relatively short period of before and after M\&A; mostly between one or two years before and after M\&A, whereas only few studies assessed three years before and after M\&A. As a matter of fact, it is hard for companies to have achieved synergy between this short period while many factors intervene in the integration process to reap the benefits from M\&A. Nonetheless, Haas and Hodgson (2013) stated that the synergy would be delivered among all departments wholly by the end of the third year after M\&A had been executed. Therefore, the result of full synergy logically can be seen in the financial performance of the fourth year after $M \& A$.

Thus, this study compare more varied accounting ratios to analyze the financial performance of the company; consist of current ratio to measure liquidity, total assets turnover, net profit margin, return on assets, return on equity and earnings per share to measure profitability, debt to equity to measure solvency. Tobin's $Q$ Ratio is used to measure market response more accurately instead of share price. The data used the newest possible data that can be obtained in the process of taking the data coming from listed companies underwent $M \& A$ between 2009 until 2012. The ratios assessed from four years before M\&A and four years after, which is longer compared to previous studies. A three-year scale of assessment, which is much shorter, ensure that the companies are in the same economic cycle and level of insight. This research also analyse further the practice of $M \& A$ in Indonesia related to the motives of M\&A in Indonesia that rarely being studied before.

\section{LITERATURE REVIEW}

\subsection{Definition of $M \& A$}

In short, merger can be described as "A+B= A or B". After merger, the merged company is ceased to exist and the assets, liability and equity of the merged company are combined to the merging company. In a merger there is usually a process of negotiation involved between two companies prior to the 
combination taking place, where both may consider that a merger would result in greater market share and the product will be available in larger geographical area (Tarigan, Yenewan, \& Natalia, 2017). On the other hand, acquisition can be described as " $A+B=A \rightarrow B$ ". In an acquisition the negotiation process does not necessarily take place. This means company $A$ buys company $B$. Company $B$ becomes wholly owned by company $A$, but company $B$ still exists in its pre-acquired form. However, the control of company $B$ has been held by company $A$, not by the previous shareholders. In another word, an acquired company usually will run as a subsidiary of the acquirer (Roberts, Wallace and Moles, 2010).

\subsection{Lifecycle of $M \& A$}

There are some identifiable stages going through by companies undergo M\&A. M\&A starts with inception stage. The senior managers from one of the company initiate the process and then followed by feasibility stage. In this stage, the financial and other areas based on the motives of doing M\&A, such as: a detailed analysis of financial characteristics, projected timescales, and synergy generation, are being assessed with complete and adequate due diligence. During feasibility stage, or at the end of feasibility stage, a company is able to commit to proceed to the next stage by allocating necessary funds and resources to implement $M \& A$.

This process is followed by pre-merger negotiation stage. In this stage, the top management from both companies negotiate the structure and format of the new combined company. Once the negotiation has been completed, an agreed result will be made into a detailed $M \& A$ contract. It explains the rights and obligations of each company in the M\&A process in terms of agreed deal. As soon as the contract is being finalized, the implementation process starts. This stage's prime point is to make the M\&A happen. After this stage onwards, the stage will be continued by longer-term stage, commissioning stage, where company has been accustomed to the new organizational structure of the organization (Roberts et al., 2010).

\subsection{Motives of M\&A}

There are two main motives causing company is willing to undergo $M \& A$. The first one is shareholder gains focusing to increase profit and thus shareholders are the one who will get the benefit; while the second one is managerial gains in which managers might have other motives than to maximize the value of the company (Motis, 2007). According to Tarigan et al. (2017), the factor resulting in shareholder gains are:

1. Growth: most companies opt to grow by external means such as M\&A. This is done to gain access to a new product line, customer segment, or geography. By using this strategy, company does not need to start from scratch to do the expansion. However, financial resources needed to do M\&A is bigger since goodwill is needed to motivate target company who already has good skill needed is willing to participate in the deal. This big financial resources needed at first, nonetheless, will be paid back in a shorter period of time compared to internal growth and in more certain manner.

2. Synergy: combining two companies results an added value larger than each company stand on its own or "1+1=3" standpoint. This value added can be obtained from larger market share and area, enhanced technology or knowhow to expand offerings, decreasing labor costs and operating costs and achievement of economies of scale (Eliasson, 2011). There are two kinds of synergy: 1) Operating synergy consists of economies of scale where the higher the production the lower the marginal cost and economies of scope 
where the average cost of producing two products separately falls when the products are produced together (Tamosiuniene \& Duksaite, 2009); 2) Financial synergy is achieved through savings from cost of capital as companies may have more bargaining power to get competitive interest rate, loan term and bigger amount from the bank (Said, 2008).

3. Diversification: companies try to minimize bankruptcy risk through investment in different and unrelated industry. Therefore, if one sector of business is in its lowest point the company can still maintain good performance in the end.

4. Horizontal integration: enable company to have larger market share and to provide better service to the customers in one industry. It is not unusual for companies with this motive to merge with or acquire competitors.

5. Vertical integration: enable companies to minimize dependence towards the suppliers or distributors, hence system to reduce costs can be applied, such as JIT system, and to benefit from internal transfer pricing; which will result in lower cost of goods sold and tax savings.

6. Improved Management: diffusion of the knowledge of both companies will result in product or process innovation, while integration of $R \& D$ result in timely improvement and innovation.

7. Tax motive: acquisition premium should go into assets which will result in increasing depreciation expense and decreasing tax liabilities. This motive is not crucial anymore since nowadays different tax regulation for company which just undergoes M\&A is applied (Motis, 2007). Moreover, tax advantages can also be gotten from internal transfer pricing where value added tax will only need to be paid once causing the end price of the product is lower compared to competitor.

\subsection{Factors Affecting the Success and Failure of M\&A}

According to Mallikarjunappa and Nayak (2007), there are some important reasons for failures of Mergers and Acquisition:

1. Size issues: a mismatch in the size between acquirer and the target company, often called acquisition indigestion, this happens when company acquire too big company or not giving small target the time and attention required.

2. Diversification: failed to manage due to lack of industry knowledge, lack of focus, and inability to gain meaningful strategies. It is found that $42 \%$ of poor acquisition performance were conglomerate acquisition in which the acquirer and target company lack of familiarity.

3. Poor cultural fit: the match between administrative and cultural practices, and personnel characteristics is critical. This will ease communication and minimize misunderstanding during implementation stage, thus ease the process of knowledge and skills transfer. Poor cultural fit will lose company the "key employees" as people are resistant to change and will further affect the performance of the company. A good cultural fit between two companies becomes competitive advantage of the new company leading to the sustainable success of $M \& A$.

4. Poor strategic fit: M\&A with strategic fit can improve profitability through reduction in overheads, effective utilization of facilities, lower cost of capitals and deployment of surplus cash for expanding business with higher returns. Strategic fit includes the business philosophies of the two entities (ROI versus market share), the time frame for achieving goals (short-term versus 
long-term), and the way in which assets are utilized (high capital investment versus asset stripping mentality).

5. Incomplete and inadequate due diligence: Lack of due diligence is lack of detailed analysis of all important features of the two companies. The most important aspects in due diligence are duration of conducting due diligence and the numbers of the people conducting it. Due diligence must be done in a realistic duration. Conducting it too fast because of trust to acquiring companies may omit some critical facts, such as the possibility of fraud in the financial statements. The numbers of the people doing it must be enough to get sufficient information for M\&A success (Tarigan et al., 2017).

6. Poorly managed integration: integration of companies requires high quality management; it must be planned and designed in the pre-acquisition period so that the implementation can be smooth. Retaining the best talent and giving equal opportunity from both companies will avoid uncertainty and ambiguity that destabilizes company and the decision made can be seen as fair, correct and impartial. As a result, companies can benefit from momentum and enthusiasm of the employees that are still present to achieve synergy faster.

7. Failure of leadership role: one style should adapt in merger. The resistance to adapt will lead to the failure of M\&A (Tarigan et al., 2017). Top management follow-up is essential to go with a clear road map of actions and set the pace of the integration. In addition, talking to employees is the important factor during the period of M\&A to minimize uncertainty and maintain the trust of the employee.

\subsection{Measuring the Performance of M\&A}

Whilst few mergers and acquisition were a huge success, many of them had failed during the adjustment period. There were a lot of disruptions that happened during the post-acquisition period. The combined companies need time to achieve synergy (Akinbuli \& Kelilume, 2013). Therefore, the measurement of the overall success of merger and acquisition is an important factor to be aware of; as the indicators of the success of M\&A should ensure the sustainability of the new company and achievement of financial result, not merely in the short run, but in the long run (Adjei \& Ubabuko, 2011). According to Moini \& Wang (2012), there are five commonly used performance evaluation approaches in M\&A field. They are:

1. Event Studies, (short-run and long- run)

2. Accounting-based measures,

3. Managers' perceived performance,

4. Expert informants' assessment, and

5. Divesture (Divestment measure).

However, Cording, Christmann and Weigelt (2010) reported that 92 percent of empirical studies used event study and accounting methods. Zollo and Meier (2008) also confirmed these two most used methods in 1970 until 2006 stating that $40 \%$ of researches conducted by experts used short-term event studies method, $28 \%$ used accounting-based measure, 19\% used long-term event studies, 14\% used managers' perceived performance, and the remaining used other varied methods.

1. Event Studies: designed to measure whether there is an abnormal stock price effect associated with an unanticipated event (M\&A), holding that stock returns reflect quick, unbiased, rational, and risk-adjusted expectations of the 
value of the firm in forthcoming period based on the arrival of new information based on market efficiency theory.

2. Accounting-based measures: takes a long-term, actual and realized returns of acquisition performance since any benefit arise from the deal will be reflected in the company's financial statements. This usually consists of a comparison of accounting measures prior and subsequent of M\&A.

Epstein (2005) suggested that evaluating M\&A based on share price in shortterm only is not possible since M\&A needs time to integrate and achieve synergy before the result can be shown through financial statement and market price. Furthermore, according to Krishnakumar and Sethi (2012), event study mostly used in developed country, while it may not work properly in developing country's market such as India as the efficiency of the market is different.

Looking back to previous findings of Krishnakumar and Sethi (2012) and Zollo and Meier (2008), it was said that both accounting and market measurement must be used simultaneously to assess the performance after M\&A in a more comprehensive way. Considering that this study will be conducted in Indonesia which has lower market efficiency compared to developed countries, therefore Tobin's $Q$ was chosen to measure market performance more accurately in addition of accounting measures since the sustainability of a company's performance is reflected in profitability and efficiency of the company which can only be measured through accounting-based ratio.

\subsection{Accounting Measurement}

There are several financial ratios that can be used to assess some business segment. According to Weygandt, Kimmel and Kieso (2011), the ratios are classified into three groups which are:

1. Liquidity ratio: measures company's capability to pay its maturing liabilities and to meet unexpected need for cash. One of liquidity ratios' measurements going to be used in this research is current ratio (CR). It expresses the extent to which the current liabilities of a business (i.e. liabilities due to be settled within 12 months) are covered by its current assets (i.e. assets expected to be realized within 12 months). It is calculated by:

$$
\text { Current ratio }=\frac{\text { Current assets }}{\text { Current Liabilites }}
$$

2. Profitability Ratios: measures the return of invested capital and show the highest managerial efficiency or operating success of a company. There are several profitability ratios that can be used, such as:

a. Total Assets Turnover (TATO): measures how efficient a company uses its assets to generate sales. It does measure how much sales can be generated in every dollar of assets and reflect the speed of a company in using its assets. It is calculated by:

$$
\text { Total asset Turnover }=\frac{\text { Net Sales }}{\text { Total Assets }}
$$

b. Net profit Margin (NPM): a measure of the percentage of each dollar of sales that results in net income. It is the percentage of revenue remaining after all operating expenses, interest, taxes, and preferred stock dividends have been deducted from a company's total revenue. This ratio shows how efficient the company manages its operations (Ross, Westerfield, \& Jaffe, 2012). It can be calculated by:

$$
\text { Net Profit Margin }=\frac{\text { Net Profit }}{\text { Sales }}
$$


c. Return on Assets (ROA): a measure of profit per dollar of assets. The ratio shows how well a company is in managing its assets to make a profit and is often used to compare companies within the same industry. It is computed by:

$$
\text { Return on Assets }=\frac{\text { Net Profit }}{\text { Total Assets }}
$$

d. Return on Equity (ROE): measures a firm's efficiency at generating profits from every rupiah of net assets. Its formula is:

$$
R O E=\frac{\text { Net Profit }}{\text { Total Ordinary Equity }}
$$

e. Earnings per Share (EPS): the portion of a company's profit allocated to each outstanding share of ordinary shares. It is calculated by:

$$
E P S=\frac{\text { Net Income }}{\text { Outstanding Ordinary Shares }}
$$

3. Solvency Ratio: measures how much the company owes compared by its size and whether it is getting into much more debt or improving its situation. It is calculated by:

$$
D E R=\frac{\text { Long }- \text { term debt }}{\text { Ordinary Shareholders' Equity }}
$$

\subsection{Market Measurement}

Tobin's $Q(Q)$ is one of the way to calculate the market value and to assess the market performance of a company (Nuswandari, 2009). The increase in share price will have the positive impact towards the market value of the company (Saviera \& Sasongko, 2012). According to Nuswandari (2009), tobin's $Q$ for companies in Indonesia can be calculated by:

$$
Q=\frac{\text { Market Valule of Equity }+ \text { Debt }}{\text { Total Assets }}
$$

where:

Market Value of Equity = the number of outstanding shares in the market in the year-end times with the share price. Debt $=$ (current liabilities-current assets) + inventory + long-term debt.

\subsection{The Impact of M\&A towards Accounting Measurement}

Based on the theory of the impact of merger and acquisition (M\&A) towards the financial performance of the company, the size of the company is automatically getting bigger because of the assets, liabilities, and equity are being combined together so that the financial performance of the company should be better compared to the performance before M\&A (Gunawan, 2013). Based on the research done by Gunawan (2013), several financial ratios showed significant difference between before and after M\&A. Net profit margin (NPM), earnings per share (EPS), current ratio (CR), and Debt to equity ratio (DER) showed significant difference after $M \& A$, whilst total asset turnover ratio (TATO), return on assets (ROA), and return on equity (ROE) did not show significant difference. However, MANOVA test shows that there was no significant difference in overall financial performance. This is consistent with the research done by Aprilita, Tjandrakirana and Aspahani (2013), they found there were no significant difference between CR, TATO, ROA, ROE, EPS, and DER before and after M\&A. The tests conducted to analyze the impact simultaneously also showed no significant difference. The result 
of many research done has proven that the factor of failures of $M \& A$ has to be avoided as the failure in only one of these factors will avoid M\&A to be success (Saviera \& Sasongko, 2012).

$\mathrm{HA}$ : There is significant difference in accounting measurement of companies in several industries in Indonesia comparing before and after M\&A.

\subsection{The Impact of M\&A towards Marketing Measurement}

Singh and Mogla (2010) said that assessing the performance of mergers and acquisition (M\&A) can be seen from accounting data and market data. Market performance is the management ability to create the market value of the company and is related to the market value in the stock exchange. This reflects the prospects of the companies according to the shareholders' perception or expectation (Gunawan \& Surakartha, 2013). Tobin's $Q$ is one of the way to calculate the market value and to assess the market performance of a company (Nuswandari, 2009). Tobin's $Q$ is the ratio of the market value of company's assets (as measured by market value of its outstanding stock and debt) to the replacement cost of the firm's assets (Tobin, 1969). The basic idea of Tobin's $Q$ was to examine a causal relationship between $Q$ and investment. If $Q$ exceeded unity, companies would have incentive to invest, i.e. through expansion or acquisition since the present value of the future earnings from such capital will be greater than its cost. It also shows the growth opportunity of the company and the management's ability in creating value (Lindenberg \& Ross, 1981).

HB: There is significant difference in market measurement of companies in several industries in Indonesia comparing before and after M\&A.

\section{RESEARCH METHOD}

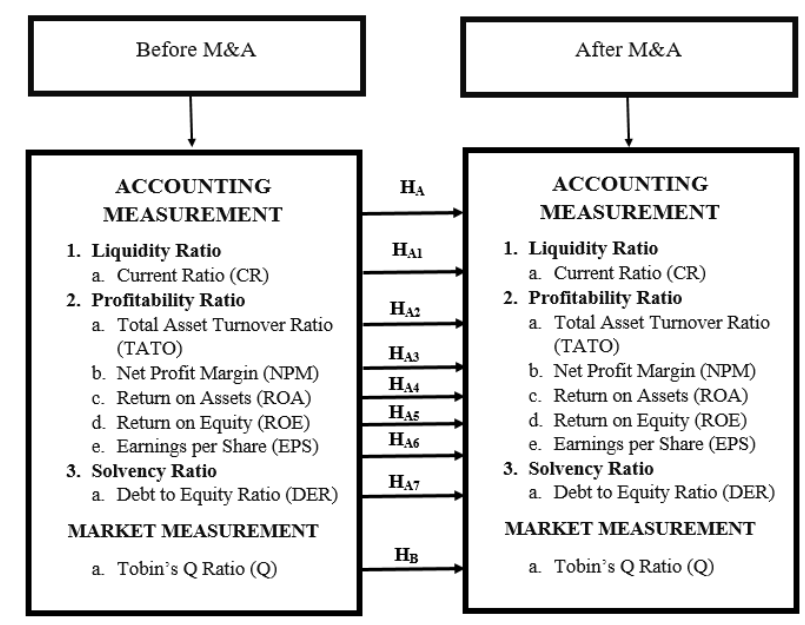

Figure 1. Research Model

The impact on financial performance was studied from seven ratios in this study, which are: CR, TATO, NPM, ROA, ROE, EPS and DER; while the market performance will be studied based on Tobin's $Q$ Ratio $(Q)$. The mean of these ratios will be compared between four years before and four years after M\&A Using IBM SPSS Statistics 21, each of the data from all four industries separately and simultaneously will be assessed with Normality Test. If the data is normallydistributed, then Paired Sample T-Test will be used to compare means of every ratio; otherwise the Wilcoxon Signed Rank Test will be used. After that, MANOVA Test will be conducted to know the impact of financial performance simultaneously. 
The study uses secondary data which obtained from Komisi Pengawas Persaingan Usaha (KPPU), Indonesia Capital Market Directory (ICMD), Annual report, Bloomberg and Indonesia Stock Exchange (IDX) collected with documentation technique. The companies are chosen using purposive sampling technique, in which the sample is chosen based on certain criteria that are suitable for this study. These companies then eliminated by some criteria so that the number of companies analyzed are 17 in total comprises of 5 companies from property and real estate, 4 from trading and services, 4 from mining and consumer goods industry. Each company will be assessed from eight annual reports; four years before M\&A and after M\&A; thus, resulted in 136 annual reports in total.

Table 1. Sample Selection

\begin{tabular}{ll}
\hline Sampling Criteria & $\begin{array}{l}\text { Number of } \\
\text { Samples }\end{array}$ \\
\hline $\begin{array}{l}\text { Number of merger and acquisition (M\&A) transactions during } \\
2009 \text { until } 2012\end{array}$ & 388 \\
Number of companies in financial or banking sectors & $(13)$ \\
Number of companies being acquired by companies not listed in & $(292)$ \\
IDX; by private or foreign companies & \\
Number of companies being acquired by companies listed-not- & $(29)$ \\
in-the-whole-period-of-study in IDX & \\
Number of companies which underwent M\&A more than once in & $(32)$ \\
the period of study & \\
Number of companies which are not included in property \& real & $(3)$ \\
estate, trading \& services, mining, or consumer goods industry & \\
Number of companies do not have full financial data needed for & $(2)$ \\
the research & 17 \\
Total companies used in this research & (x 8) \\
Annual report assessed per companies & 136 \\
\hline
\end{tabular}

\section{DATA ANALYSIS AND DISCUSSION}

\subsection{Descriptives Statistics}

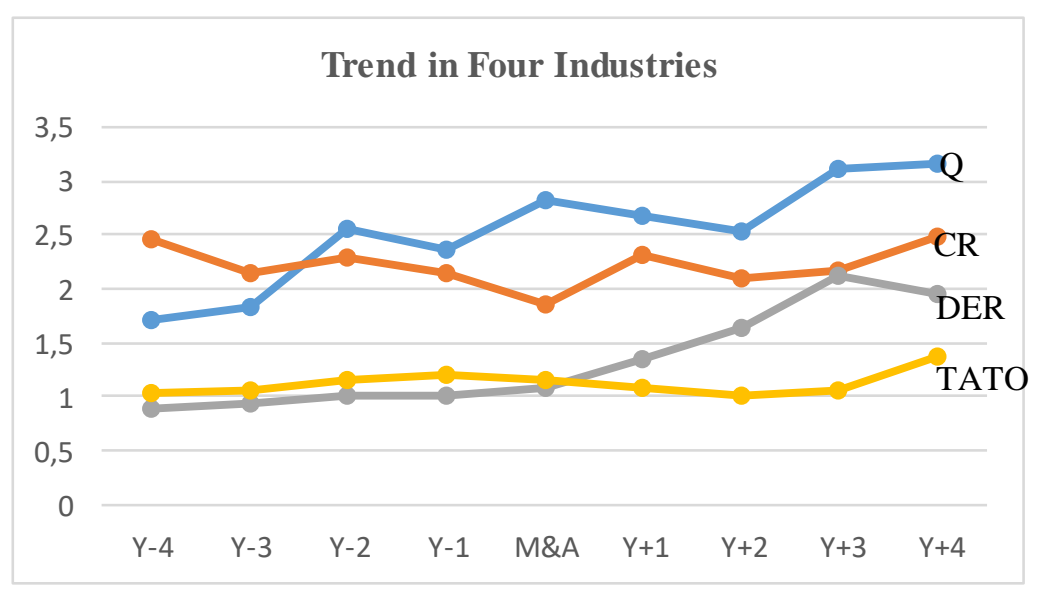

Figure 2. Trend in Four Industries

It can be seen from the graph that $C R$ trend is increasing, as well as DER and $Q$. CR after M\&A is rather going up and down compared to period before M\&A, but $D E R$ and $Q$ after $M \& A$ is constantly above the period before. It should be noted that $Q$ in the year of M\&A happened increased significantly compared to the year 
before and then slightly decreased in the subsequent year. However, in the third year after M\&A it increased significantly once more. As for DER, it started to increase significantly in the first year after $M \& A$ and had kept on increasing significantly in the subsequent years. It peaked on the third year after M\&A, even though slightly decreased in the fourth year. Moreover, it is found that TATO had been the same in the first three years after M\&A, yet in the fourth year after M\&A TATO increased significantly.

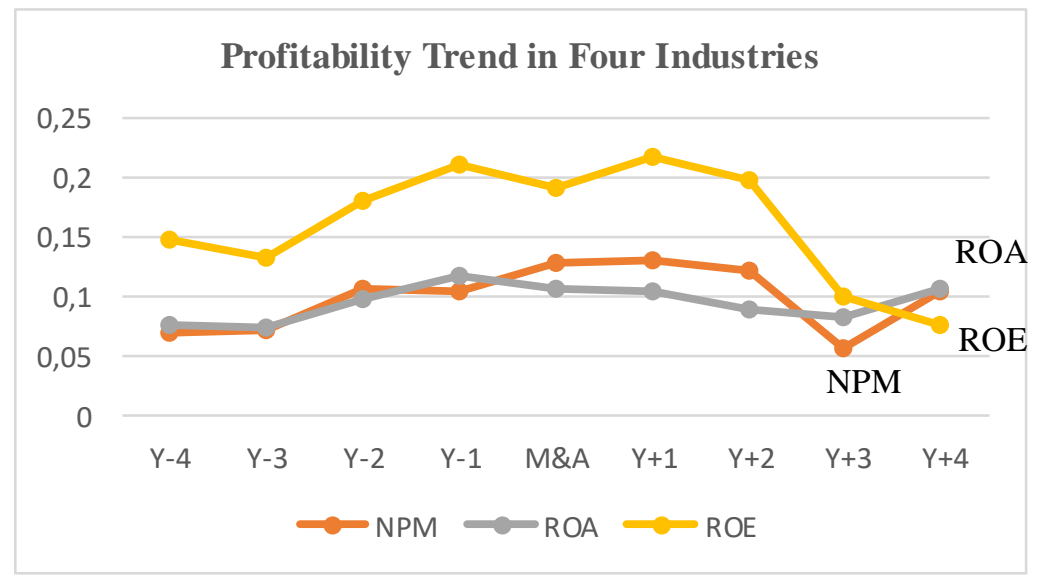

Figure 3. Profitability Trend in Four Industries

In Figure 3, it is found that ROE between before and after M\&A had been almost the same, however in the last two years of observations ROE suddenly decreased. On the other hand, NPM had always steadily increased in the first years after M\&A but decreased quite dramatically in the third year after M\&A and back to normal in the fourth year. ROA, nevertheless, had been firmly increased even the increase had been so diminutive.

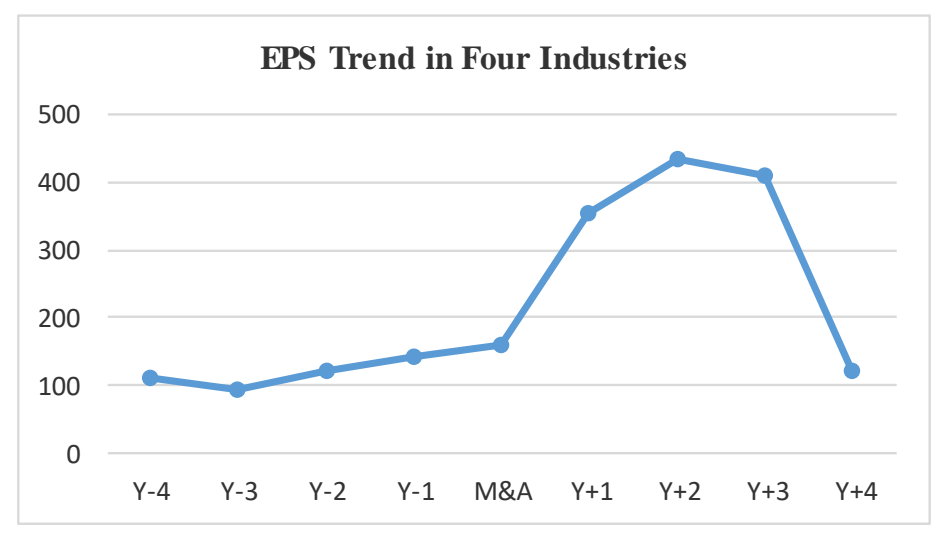

Figure 4. EPS Trend in Four Industries

From Figure 4, it can be seen that EPS, as one of profitability ratios, had increased significantly in the period after $M \& A$, yet in the fourth year after $M \& A$ it suddenly dropped to the same point before $M \& A$. 


\subsection{Normality Test}

Table 2. Result of Normality Test

\begin{tabular}{lcccl}
\hline \multicolumn{1}{c}{ Var. } & $\begin{array}{c}\text { Sig. } \\
\text { (Bef.) }\end{array}$ & $\begin{array}{c}\text { Sig. } \\
\text { (Aft.) }\end{array}$ & \multicolumn{1}{c}{ Conclusion } & \multicolumn{1}{c}{ Hypothesis Test } \\
\hline CR & 0.089 & 0.004 & Abnormal Distribution & Wilcoxon Signed Rank Test \\
TATO & 0.415 & 0.008 & Abnormal Distribution & Wilcoxon Signed Rank Test \\
NPM & 0.178 & 0.137 & Normal Distribution & Paired Sample T-Test \\
ROA & 0.001 & 0.001 & Abnormal Distribution & Wilcoxon Signed Rank Test \\
ROE & 0.004 & 0.001 & Abnormal Distribution & Wilcoxon Signed Rank Test \\
EPS & 0.001 & 0.000 & Abnormal Distribution & Wilcoxon Signed Rank Test \\
DER & 0.355 & 0.000 & Abnormal Distribution & Wilcoxon Signed Rank Test \\
Q & 0.000 & 0.000 & Abnormal Distribution & Wilcoxon Signed Rank Test \\
\hline
\end{tabular}

When the significance level is less than 0.05 then the data is not normally distributed; otherwise the data is normally distributed. It can be concluded from the table above that Wilcoxon Signed Rank Test will mainly be used in testing most of the dependent variables since almost all of the data is normally distributed, except for Net Profit Margin where Paired Sample T-Test will be used.

\subsection{Hypothesis Testing}

Table 3. The Result of Hypothesis Test in Four Industries

\begin{tabular}{|c|c|c|c|c|c|}
\hline Var. & $\begin{array}{l}\text { Mean } \\
\text { (Bef.) }\end{array}$ & $\begin{array}{l}\text { Mean } \\
\text { (Aft.) }\end{array}$ & Diff. & Sig. & Concl. $(\alpha=0.1)$ \\
\hline \multicolumn{3}{|c|}{$\begin{array}{l}\text { CR, TATO, NPM, ROA, } \\
\text { ROE, EPS, DER }\end{array}$} & $F=2.237$ & 0.035 & $\mathrm{H}_{\mathrm{A}}$ is accepted \\
\hline $\mathrm{CR}$ & 2.2661 & 2.2676 & 0.0015 & 0.065 & $\mathrm{H}_{\mathrm{A} 1}$ is accepted \\
\hline TATO & 1.1146 & 1.1296 & 0.0149 & 0.016 & $\mathrm{H}_{\mathrm{A} 2}$ is accepted \\
\hline NPM & 0.0889 & 0.1040 & 0.0151 & 0.434 & $\mathrm{H}_{\mathrm{A} 3}$ is rejected \\
\hline ROA & 0.0922 & 0.0958 & 0.0036 & 0.728 & $\mathrm{H}_{\mathrm{A} 4}$ is rejected \\
\hline ROE & 0.1690 & 0.1482 & $(0.0208)$ & 0.751 & $\mathrm{H}_{\mathrm{A} 5}$ is rejected \\
\hline EPS & 116.69 & 329.60 & 212.91 & 0.175 & $\mathrm{H}_{\mathrm{A} 6}$ is rejected \\
\hline DER & 0.9593 & 1.7626 & 0.8033 & 0.000 & $\mathrm{H}_{\mathrm{A} 7}$ is accepted \\
\hline Q & 2.1183 & 2.8762 & 0.7580 & 0.021 & $\mathrm{H}_{\mathrm{B}}$ is accepted \\
\hline
\end{tabular}

Based on Table 3, current ratio (CR), reflecting the liquidity of the company, has been proven to be significantly affected by M\&A as the mean after M\&A is increasing. Total assets turnover (TATO) has been the only profitability ratio that is significantly affected by M\&A. Its mean has also been increasing compared to the period before M\&A. The mean of other profitability ratios, such as net profit margin (NPM), return on assets (ROA), and earnings per share (EPS) also increased yet did not significant, unless return on equity (ROE). The mean of ROE has been decreasing for the period after M\&A compared to the period before, although the decrease is not significant.

Solvency ratio has been highly affected by $M \& A$ as the mean is increasing. The increase of solvency ratio, debt to equity ratio (DER) in this study, does not necessarily mean negative to the financial performance as long as it is considered well by the management. Moreover, the MANOVA test showed that overall $f$ accounting measurement has significantly affected by M\&A in companies from all four industries. Furthermore, the mean of Tobin's $Q$ ratio $(Q)$ also increased significantly reflecting that market performance are positively impacted by the M\&A. 


\subsection{Analysis of the Result}

Table 4. The Motives Reflected

\begin{tabular}{llll}
\hline Var. & \multicolumn{2}{c}{ Conclusion $(\boldsymbol{\alpha}=\mathbf{0 . 1})$} & \multicolumn{1}{c}{ Motives } \\
\hline $\begin{array}{llll}\text { CR, TATO, NPM, ROA, } \\
\text { ROE, EPS, DER }\end{array}$ & $\mathrm{H}_{\mathrm{A}}$ is accepted & Increase & Growth \\
CR & $\mathrm{H}_{\mathrm{A} 1}$ is accepted & Increase & $\begin{array}{l}\text { Growth/Horizontal } \\
\text { Integration }\end{array}$ \\
TATO & $\mathrm{H}_{\mathrm{A} 2}$ is accepted & Increase & $\begin{array}{l}\text { Growth/Horizontal } \\
\text { Integration }\end{array}$ \\
NPM & $\mathrm{H}_{\mathrm{A} 3}$ is rejected & Increase & Operating Synergy \\
ROA & $\mathrm{H}_{\mathrm{A} 4}$ is rejected & Increase & Operating Synergy \\
ROE & $\mathrm{H}_{\mathrm{A} 5}$ is rejected & Decrease & Operating Synergy \\
EPS & $\mathrm{H}_{\mathrm{A} 6}$ is rejected & Increase & Operating Synergy \\
DER & $\mathrm{H}_{\mathrm{A} 7}$ is accepted & Increase & Financial Synergy \\
$\mathrm{Q}$ & $\mathrm{H}_{\mathrm{B}}$ is accepted & Increase & Growth \\
\hline
\end{tabular}

The increase of CR and TATO can be seen as a result of the rapid increase of sales. Sales revenue will be the first to be impacted since sales and marketing is one among all departments that is the fastest to be integrated (Haas \& Hodgson, 2013). The current assets, in the form of receivables, will increase significantly higher compared to the liabilities' amount; although payables are also inevitably increasing proportionately to sales increase. Thus, the amount of money in circulation to finance daily operation will be much higher (Adjei \& Ubabuko, 2011). Moreover, two motives to undergo M\&A for companies is to grow faster and integrate horizontally as the certainty is higher even though the capital needed is higher. Horizontal integration motive also straightway boosts sales as the market share automatically gets bigger for the combined companies; not to mention if both companies have strengths being complement to each other (Tarigan et al., 2017). Hence, sales and marketing advancement can be concluded as the main goal and main focus of newly combined companies in Indonesia based on the result of the study.

The increase of NPM, ROA and EPS showed the efficiency of the operation. This shows that the portion of the net profit remaining had been increasing although the interest expense must have been higher; which proved that operational synergy of the company at least has been slightly achieved from economies of scale and economies of scope allowing overhead and material costs to decrease. The significant increase of DER may be caused by financial synergy that mostly is one of the motives for companies to going through M\&A. Financial synergy is achieved through savings from cost of capital that can be gained almost straightaway after M\&A. The companies, then consequently, have more bargaining power to get competitive interest rate, longer loan-term, and bigger amount from the bank (Tarigan et al., 2017). It is logical for the company to increase the total amount of debt since the increase of debt may cause increasing ROE to some extent. Yet, too high DER is also exposing shareholders and lenders to risk and eventually decrease ROE as it plays a role as an amplifier. Higher DER will provide higher net income if operating profit increase, otherwise all operating profit will be consumed by interest expense. This can be considered unfavorable for financial performance of a company (BPP Learning Media, 2015). In this study, it was found that ROE had been decreased and DER increased showing the operating profit did not increase as much as needed to cover the interest expense according to the theory, despite 
of the increase of NPM and ROA. Therefore, it can be said that the operational synergy needs longer time to be achieved fully since the ROE had been decreasing despite of the increase of other profitability ratios. This might be caused by the experience of Indonesian companies that had just started M\&A in 1990s, while other countries such as the USA had started M\&A practices in 1900s (Economywatch, 2010).

Haas and Hodgson (2013) stated that operation synergies can be delivered fully in the companies in the USA by the middle of the third year after M\&A. Companies in Indonesia, can be said as newcomers compared to the ones in the USA, obviously need much longer time than three years to deliver synergy wholly based on the result. According to Saviera and Sasongko (2012), this process of integration can be made faster by conducting appropriate due diligence and assessing thoroughly cultutal and strategic fit of two companies going to be merged. In addition, leadership role can not be underestimated in intergration phase as it is critical to keep the communication towards the employees. Moreover, it should be taken into consideration that some of the companies acquire their own subsidiaries, thus no synergy that can be achieved in reality as there is no change in management.

The increase of the average of DER, furthermore, has also proven that the M\&A method of Leverage Buyout (LBO) has not broadly been applied. This method occurs firstly in the US before economic crisis of 2008 where the M\&A transaction is financed with debt due to lower interest rate and the availability of fund; the type of debt typically used by the companies is asset-based lending and subordinate debt. Should the companies adopt this method, the DER trend after M\&A will be decreasing (Tarigan et al., 2017). This might happen as the current interest rates in Indonesia can not be said as really low and some companies selected to be samples were big companies which able to guarantee the availability of the fund to merge with or acquire other companies.

Furthermore, MANOVA Test showed that there was significant increase in overall financial performance. Paired Sample T-Test also showed $Q$ had significantly increased in this study. As $Q$ had increased significantly in the year of $M \& A$, this showed that market had expected companies to perform better after $M \& A$ because of value added obtained from the synergy (Eliasson, 2011). In subsequent year after $M \& A, Q$ still consistently increased reflecting the improved accounting measurement. As one component of $Q$ is share prices, this might show semi-strong market efficiency in Indonesia where the share prices reflect both all relevant information about past price movements and all publicly available information (Stevens, 2005).

\section{CONCLUSION AND SUGGESTIONS}

\subsection{Conclusions}

The result of the study showed that companies undergoing $M \& A$ in the period of 2009 until 2012 in property and real estate, trading and services, mining, and consumer goods industry had proven that companies in Indonesia focus more on growth strategy, shown by the increase of liquidity ratio. Solvency had also increased significantly since lower cost of capital can be achieved through financial synergy. However, this had come at the expense of ROE that might be caused by the increasing of operating profit that had not been as high as expected. The operating synergy might need longer time and extra focus to be achieved fully as 
the experience of Indonesian companies in M\&A can be said fewer than other foreign companies. Overall accounting measurement had been significantly increasing and so had market performance showing that the market expected M\&A would improve the accounting performance of companies benefiting from operational and financial synergies in the future years. This showed that Indonesia has had semi-strong market efficiency.

\subsection{Suggestions}

Based on the findings in the study, it is suggested for companies in Indonesia not to only focus on growth and financial strategy motives, but also on operating synergy. This can be achieved by studying from foreign companies to plan M\&A more thoroughly, especially in the feasibility stage in order to have adequate and complete due diligence regarding all of the important features such as organization status, accounting standard and valuation of acquisition to ensure there is no overpayment of a transaction causing profitability ratios to suffer in the period after M\&A. Strategic and cultural fit of both companies are also to be assessed in this stage since it is critical factor to determine whether newly combined companies can achieve the synergy or not. The planning stage has also to be taken more seriously in order to ease the integration. In addition, top management has to plan thoroughly exactly what has to be done in the implementation period to ensure the synergy can be achieved faster and profitability can increase. Moreover, the companies should evaluate M\&A based on its motives to undergo $M \& A$ internally. This study analyzed the impact of $M \& A$ towards financial performance of the companies in the period of 2009-2012. The result of this study, however, is not necessarily compatible for all situation of M\&A as it is affected by the economic cycle that happened in the period of the study. Every economic cycle has their own challenge so it must be analyzed accordingly. 


\section{REFERENCES}

Adjei, E. K., \& Ubabuko, K. 2011. The Consequences of Post-Merger and Acquisition Performance in Listed and Non-Listed Companies in Sweden. Gotland University.

Aprilita, I., Tjandrakirana, R., \& Aspahani. 2013. Analisis perbandingan Kinerja Keuangan Perusahaan Sebelum dan Sesudah Akuisisi (Studi pada Perusahaan Pengakuisisi yang Terdaftar di BEI periode 2000-2011). Jurnal Manajemen dan Bisnis Sriwijaya, 11(2), pp.99-114.

Akinbuli, S. F., \& Kelilume, I. 2013. The Effects of Mergers and Acquisition on Corporate Growth and Profitability: Evidence from Nigeria. Global Journal of Business Research, VII, pp.43-58.

BPP Learning Media. 2015. ACCA Approved Study Text for Paper Financial Management (8th ed.). London: BPP Learning Media Ltd.

Carrey, D. 2000. Lessons from Master Acquirers: A CEO Roundtable on Making Mergers Succeed. Harvard Business Review.

Cording, M., Christmann, P., \& Weigelt, C. 2010. Meauring Theoretically Complex Constructs: The Case of Acquisition Performance. Strategic Organization, 8(1), pp.11-41.

Duff \& Phelps Singapore Pte Ltd. 2016. Transaction Trail Annual Issue 2016. Retrieved from Duff and Phelps: https://www.duffandphelps.com/insights/publications/valuation/transactiontrail-annual-issue-2016 [Accessed February 20th 2018]

Economywatch. 2010. Retrieved June 5, 2017, from http://www.economywatch.com/mergers-acquisitions/history.html [Accessed February 20th 2018]

Eliasson, S. 2011. Synergies in Mergers and Acquisitions. Master's Thesis in Business Administration. Retrieved from Eliasson: https://www.divaportal.org/smash/get/diva2:512472/FULLTEXT01.pdf [Accessed February 20th 2018]

Epstein, M. 2005. The Determinants and Evaluation of Merger Success. Business Horizons, 48, pp.37-46.

Gunawan, K. H., \& Surakartha, I. M. 2013. Kinerja Pasar dan Kinerja Keuangan Sesudah Merger dan Akuisisi di Bursa Efek Indonesia. E-Journal Akuntansi Universitas Udayana, pp.271-290. 
Haas, B., \& Hodgson, A. 2013. What Shape is Your Curve? Retrieved from A.T. Kearney: https://www.atkearney.com/mergers-acquisitions/article?/a/whatshape-is-your-curve [Accessed February 20th 2018]

Halim, M. T. 2016. Indonesia 2016: Foreign Investment Opportunities \& Trends. Retrieved March 8, 2017, from Asia Briefing: http://www.asiabriefing.com/news/2016/03/indonesia-2016-foreigninvestment-opportunities-trends/ [Accessed February 20th 2018]

Krishnakumar, D., \& Sethi, M. 2012. Methodologies Used to Determine Mergers and Acquisitions' Performance. Academy of Accounting and Financial Studies Journal, 16(3).

Lindenberg, E. B., \& Ross, S. A. 1981. Tobin's Q Ratio and Industrial Organization. The Journal of Business, 54(1), pp.1-32.

Mallikarjunappa, T., \& Nayak, P. 2007. Why do Mergers and Acquisition Quite Often Fail? AIMS International, 1(1), 53-69.

Moini, H., \& Wang, D. 2012. Performance Assessment of Mergers and Acquisition: Evidence from Denmark. E-Leader Berlin 2012, pp.1-15.

Motis, J. 2007. Merger and Acquisition Motives. Crete: University of Crete.

Nuswandari, C. 2009. Pengaruh Corporate Governance Index terhadap Kinerja Perusahaan pada Perusahaan yang Terdaftar di Bursa Efek Jakarta. Jurnal Bisnis dan Ekonomi, 16(2), pp.70-84.

Roberts, A., Wallace, W., \& Moles, P. 2010. Mergers and Acquisitions (2nd ed.). Edinburgh: Heriot-Watt University.

Said, R. M., Nor, F. M., Low, S. W., Rahman, A. A. 2008. The Efficiency Effects of Mergers and Acquisitions in Malaysian Banking Institutions. Asian Journal of Business and Accounting, 1 (1), pp.47-66

Saviera, G. A., \& Sasongko, C. 2012. Analisis Merger dan Akuisisi Perusahaan Non Keuangan yang Terdaftar di Bursa Efek Indonesia Periode 2000-2008.

Singh , F., \& Mogla, M. 2010. Market Performance of Acquiring Companies. Paradigm, 14(1), pp.72-84.

Stevens, J. 2005. Retrieved from American University in Bulgaria: http://home.aubg.edu/faculty/didar/ECON\%20402/A\%20brief\%20summary\% 20of\%20q-theory.pdf [Accessed February 20th 2018]

Tamosiuniene, R., \& Duksaite, E. 2009. The Importance of Mergers and Acquisitions in Today's Economy. KSI Transactions on Knowledge Society, 2(4), pp.11-15. 
Tarigan, J., Yenewan, S., \& Natalia, G. 2017. Merger \& Akuisisi: Perspektif Strategis dan Kondisi Indonesia. Yogyakarta: Ekuilibria.

Tegos, M. (2016). Tech leads investment in Singapore, Malaysia, and Indonesia in 2016 despite slowdown. Retrieved from Techinasia: https://www.techinasia.com/duff-phelps-transaction-trail-report-2016 [Accessed February 20th 2018]

Timmerman, A. 2017. Indonesia 2016: Riding on inbound deals, M\&A activity sees big recovery. Retrieved from Deal Street Asia: http://www.dealstreetasia.com/stories/61648-61648/ [Accessed February 20th 2018]

Tobin , J. 1969. A General Equilibrium Approach to Monetary Theory. Journal of Money, Credit, and Banking, 1(1), pp.15-29.

Weygandt, J. J., Kimmel, P. D., \& Kieso, D. E. 2011. Financial Accounting (2nd ed.). Massachusetts: John Wiley \& Sons, Inc.

Zager, K., \& Zager, L. 2006. The Role of Financial Information in Decision Making Process. Innovative Marketing, 2(3), pp.35-40.

Zollo, M., \& Meier, D. 2008. What is M\&A Performance? Academy of Management Perspectives, 22(3), pp.55-77. 